УДК 316.4

DOI https://doi.org/10.32840/2707-9147.2020.86.12

Д. С. ЧУМАЧЕНКО

аспірант кафедри соціології та соціальної роботи Класичний приватний університет

\title{
ОСОБЛИВОСТІ СОЦАЛЬНИХ УСТАНОВОК ЩОДО КОРУПЦІЇ І КОРУПЦІЙНИХ ПРАКТИК У МАСОВІЙ СВІДОМОСТІ ПЕРЕХІДНОГО УКРАЇНСЬКОГО СУСПІЛЬСТВА: СОЦІОЛОГІЧНИЙ АНАЛІЗ
}

У статті досліджено змістовні особливості соиіальних установок щзодо корупції $і$ корупційних практик в масовій свідомості перехідного украӥнського суспільства. Обтрунтовано сутність корупиії в перехідному суспільстві, яка полягає у легітимізаиії і інституиіоналізаиї неформальної нормативної системи, яка породжує корупиійні відносини на макрорівні (держава, сочіальні підсистеми), мезорівні (організачіі, установи, підприємства) імікрорівні (корупчійні взаємодії індивідуальних акторів - побутова корупиія). Виникнення та інституиіоналізачія корупиійних практик здійснюється під впливом багатьох чинників, вага яких може варіюватися в залежності від ичвілізаційного i суспільного розвитку країни, політичної системи, культурних і ментальних особливостей. Визначено, що вплив корупиіогенних факторів, а точніше їхня взаємодія, в умовах транзитивного суспільства створює умови для інституичіоналізації корупиії на різних рівнях функціонування суспільства і сочіальної взаємодії, що відображається у виникненні і домінуванні певних видів і форм корупційних практик і відносин. А отже, неформальна нормативна система у вигляді корупційних трансакцій $i$ обміну охоплює різні сфери суспільного життя. Представлено результати соціологічного дослідження соціальних установок населення України щзодо поширення корупиії $і$ корупційних практик в різних суспільних сферах, що дозволило визначити наступні змістовні особливості: 1) на рівні когнітивного компонента соціальних установок переважають уявлення про корупцію, з одного боку як деструктивне сочіальне явище, а з іншого - можливість отримати соиіальну вигоду і послугу в певних соиіальних ситуаціях, щзо є подвійним стандартом у розумінні корупиії; 2) на емоційно-оцінному рівні розуміння і сприйняття корупиї також відображає домінування подвійних стандартів у ставленні до поширення корупційних практик в украӥнському суспільстві; 3) на конотативному рівні соиіальні установки проявляються як домінуючий тип і модель поведінки щзодо корупиї - пасивність і відчуття безпорадності у протидї поширення цьього явища в суспільстві (активна позичія притаманна представникам окремих сочіальних груп, а більше 50\% населення готові використовувати корупчію як неформальну соціальну практику взаємодії із надавачами публічних, адміністративних і сочіальних послуг).

Ключові слова: корупиія, корупційні практики, чинники корупщії $і$ корупціииних практик, перехідне (транзитивне) суспільство, соціальні установки.

(C) Д. С. Чумаченко, 2020 
Постановка проблеми у загальному вигляді. В сучасному українському суспільстві, що знаходиться в умовах демократичного транзиту, склалася досить нестабільна соціально-політична і соціальноекономічна ситуація, яка обумовлена низкою чинників - недосконалість національного законодавства, неефективність діяльності державних інституцій, низький рівень політико-правової культури, усталеність неформальних соціальних практик у взаємодії держави і суспільства що породжують таке негативне соціальне явище як корупція. Найбільш проблемною характеристикою явища корупції стало те, що воно почало сприйматись на повсякденному рівні як суспільна норма, хоча на рівні вербальних висловлень більшість населення декларативно підтримує думку про небезпечність цього явища. Тому усестороннє вивчення суті корупції, причин іiї виникнення і стійкого відтворення, ставлення і установок населення до форм прояву корупційних дій і практик в сучасному українському суспільстві $є$ важливою проблемою для соціально-гуманітарного знання і реалізації державної політики щодо подолання корупції в українському суспільстві на всіх рівнях.

Аналіз останніх досліджень і публікацій. Складність і актуальність вивчення корупції як соціального феномена обумовлює підвищений інтерес з боку дослідників до даної проблеми. Іїі вивченням займається цілий ряд соціальних і гуманітарних наук: економіка, соціологія, політологія, історія, юридичні науки та інші. В останні роки почав поступово зростати інтерес до наукового комплексного осмислення корупції, число наукових публікацій різко зросло. Поглибленому дослідженню цьому феномену присвячені роботи Л. Аркуші, Л. Багрій-Шахматова, В. Борисова, Ю. Бауліна, В. Байдука, П. Геги, О. Гіди, М. Гончаренка, О. Дульського, А. Закалюка, В. Зеленецького, О. Кальмана, В. Клименка, М. Корнієнко, М. Мельника, Н. Матюхіної, М. Михальченка, Є. Невмержицького, С. Омельченка, А. Редька, А. Сафоненка, О. Свєтлова, В. Сіренка, В. Тація, О. Терещука, М. Хавронюка, Ф. Шульженка, В. Чеховича.

Осмисленню змісту і сутності корупції, іiі джерел і детермінантів значну увагу приділили зарубіжні вчені-К. Абдієв, Г. Аврек, І. Аверкієв, С. Барсукова, М. Бартошин, А. Бистрова, А. Буров, Б. Волженкін, Д. Галицький, Л. Габріель, Л. Гевелинг, С. Гурієв, Р. Гринберг, П. Джерелі, О. Дудоров, П. Кабанов, Г. Калугін, А. Кирпичніков, I. Клямкін, В. Комісарова, В. Комровский, С. Кордонський, Н. Кузнєцова, С. Ліпсет, В. Лукомський, С. Максимов, О. Нікелін, М. Нюхіна, О. Паченков, С. Перегудов, С. Пундель, Л. Петтер, С. Римський, С. Роуз-Аккерман, О. Попов, Г. Сатаров, Дж. Скотт, I. Семененко, А. Соловйов, Л. Тимофєєв, А. Чуклінов, Ф. Шульженко. Проте, не зважаючи на велику кількість публікацій щодо проблеми корупції, слід відзначити недостатність досліджень, які б передбачали комплексне вивчення соціальних установок щодо корупції як соціального явища. 
Формулювання цілей статті. Метою дослідження $є$ виявлення змістових особливостей соціальних установок громадян України щодо поширення корупції як соціального явища.

Виклад основного матеріалу дослідження. Корупцію як соціальне явище в сучасній соціологічній науці пов'язують насамперед iз дисфункціональністю соціальних процесів в перехідних або транзитивних суспільствах, яка може охоплювати всі сфери соціального простору, що виражається в соціальному феномені, за твердженням О. Стегнія [1, с. 9], «всеохоплюючої корупції». Саме в транзитивних суспільствах (до якого належить і українське суспільство) корупція досягає найвищого рівня розповсюдженості.

Корупція - багатогранне поняття, що включає в собі безліч аспектів економічного, правового, політичного характерів, а тому його слід розглядати в міждисциплінарному контексті. Тому важливо відзначити, що до визначення корупції існує різноманіття підходів. Багато хто $з$ дослідників називають це явище кримінологічним, хоча $є$ і така точка зору, що «корупція - поняття не стільки правове, скільки соціальне і моральне» [2, с. 91].

Професор Н. Кузнецова пропонує розглядати корупцію не тільки як правове, а й як соціальне, економічне та моральне явище, що завдає шкоди нормальному функціонуванню моральних та правових відносин у суспільстві й державі [3, с. 32]. Цей підхід вважається найвдалішим, бо корупцію не можна розглядати тільки в правовому аспекті. Адже, ігноруючи інші сторони корупції, які характеризують ії як соціальне, політичне, економічне явище, неможливо повністю визначити природу походження терміну «корупція».

Схоже визначення дає М. Мельник: «Корупція - це багатоаспектне соціально-економічне, політичне, правове та моральне явище, що складається з цілого комплексу протиправних дій і неетичних вчинків. Корупція - це не стільки юридична, скільки соціальна та економічна проблема. Як правова категорія корупція - збірне правове поняття, яке охоплює сукупність взаємопов'язаних правопорушень» [4, с. 34].

Соціологічний підхід до теоретичного аналізу корупції передбачає аналіз різноманіття нормативних систем і соціальних факторів, що спричиняють корупційну поведінку, та дає змогу показати диференційованість оцінок цього феномена різними суб'єктами. Корупція в соціологічної інтерпретації усвідомлюється як форма соціальних відносин, передбачає аналіз ії як форми взаємодії суб'єктів, що володіють різним обсягом ресурсів у межах різноманітних інститутів як нормативних систем.

Так, класична соціологічна думка (Е. Дюркгейм, М. Вебер, Т. Парсонс, Р. Мертон) виділяе три основні моменти в розумінні корупції як соціального явища: по-перше, як певних моделей поведінки, що мають обумовленість в ненормальних формах розподілу праці, виникнення опосередкованих надлишкових ланок; по-друге, в дефіциті або привласненні інституційних ресурсів в ситуації дисфункціональності 
соціальних інститутів; по-третє, у використанні іллегальних практик для досягнення визнаної в суспільстві легітимної мети.

Некласична соціологічна думка розглядає корупційні практики в контексті діяльнісного підходу. Згідно П. Бурд’є, корупція не субстанціональна, а є конфігурацією відносин між індивідуальними і колективними акторами. Оскільки люди переслідують різні інтереси в соціальних полях, то і корупція приймає різноманітні форми. Але основним $є$ те, що корупція є конкретна боротьба між агентами і представляє механізм капіталізації не тільки легітимних, але і не легітимних засобів [5].

В концепції Ю. Габермаса корупція розглядається як «вид стратегічних дій, в яких два або більше учасників зобов'язуються обмінюватися відносинами шляхом успішної передачі грошей або влади, яка відбувається в обхід існуючих законів і нормативних відносин» [6, с. 244]. Коррупція пояснюється через категорію життєвого світу Життєвий світ в концепції Ю. Габермаса виступає в плані комунікативної раціональності, тобто форми пізнання світу, орієнтованої на розуміння. Не менший інтерес для вивчення корупції, ніж концепція Ю. Габермаса, представляє теорія Е. Гіденса. Особливістю концепції Е. Гіденса є те, що ті або інші елементи структури (інститути, групи або ціннісно-нормативні комплекси) $є$ як результатами, так і умовами системного відтворення, яке припускає постійну трансформацію інститутів в просторі і в часі.

Отже, погляду соціологічних концепцій Ю. Габермаса і Е. Гіденса будьяка поведінка суб'єкта в системі соціальних відносин припускає ії відтворюваність, тобто наявність в системі визначених практик, які підтримують їі і обумовлюють їі необхідність. Необхідність корупційного акту обумовлена обмеженістю ресурсів суб'єкта і неможливістю подолати подібну обмеженість в рамках існуючих загальновизнаних норм. Вибір суб'єктом корупційної поведінки є формою ризикової поведінки як результату низької довіри до соціальних інститутів, а також недостатньої міжособистісної довіри клієнта до суб'єктів нормативної системи, що породжує корупцію.

Сучасні дослідники виділяють різноманітні фактори виникнення корупції в сучасному українському суспільстві. Так, Л. Білінська виділяє такі групи факторів і умов розвитку корупції:1) економічні (несприятливий режим діяльності підприємств; відсутність прозорості багатьох економічних процесів); 2) правові (відсутність цілісної системи антикорупційних засобів, невизначеність відповідальності за корупційні діяння, формальний характер чинної системи декларування доходів тощо); 3) організаційно-управлінські (відсутність чіткої регламентації діяльності посадових осіб, поширеністьу кадровій політиці випадків заміщення посад через знайомство (фаворитизм, кронізм, непотизм) тощо); 4) соціально-психологічні (нерозвиненість громадянської свідомості, корислива спрямованість державних службовців, професійна та моральна деформація посадовців тощо) [7, с. 140].

Соціокультурні і соціально-психологічні чинники корупційних практик в перехідному українському суспільстві виділяють О. Креденцер, В. Лагодзінська, О. Ковальчук: 1) наслідки радянського 
типу соціальної взаємодії в системі «влада (номенклатура, чиновники, керівники) - громадяни»; 2) особливості традиційного українського менталітету, традиційної ціннісно-нормативної системи; 3) кризовий стан суспільної свідомості - високий рівень аномійної деморалізованості населення; 4) виникнення нових соціальних груп - деформація соціальної структури суспільства тощо [8, с. 48-55].

Таким чином, сутністю корупції в перехідному суспільстві виступає легітимізація і інституціоналізація неформальної нормативної системи, яка породжує корупційні відносини на макрорівні (держава, соціальні підсистеми), мезорівні (організації, установи, підприємства) і мікрорівні (корупційні взаємодії індивідуальних акторів - побутова корупція). Виникнення та інституціоналізація корупційних практик здійснюється під впливом багатьох чинників, вага яких може варіюватися в залежності від цивілізаційного і суспільного розвитку країни, політичної системи, культурних і ментальних особливостей. Для перехідних суспільств, де відбувається трансформація соціальної, економічної і політичної системи на всіх рівнях, на нашу думку, характерний комплексний і системний вплив різних груп чинників, що формують неформальні норми і правила суспільних відносин і відповідну соціальну структуру, яка підтримує їх легітимізацію.

Описовим конструктом сприйняття і ставлення корупції як соціального явища може виступати категорія соціальної установки. Вивчення проблематики соціальних установок було започатковано соціологами У. Томасом і Ф. Знанецьким, які визначали їі як психологічний процес, що розглядається щодо соціального світу й береться, перш за все, у зв'язку із соціальними цінностями. «Цінність $є$ об’єктивною стороною установки. Відповідно, установка $є$ індивідуальною (суб'єктивною) стороною соціальної цінності» [9, с. 364]. «І в цьому сенсі установка виступає своєрідною формою зв'язку між індивідом і суспільством, будучи одночасно як елементом психічної структури особистості, так $\mathrm{i}$ елементом системи соціальних цінностей суспільства» [10, с. 41].

Зауважимо, що варто розмежовувати термін «установка» як суто психологічний, що позначає стан готовності суб'єкта діяти в тому чи іншому напрямі, і термін «соціальна установка», що використовують у соціальній психології та соціології на позначення стійкого ставлення особистості до когось або до чогось і який виявляється в думках, емоціях і соціальній діях.

Найбільш повне й загальне визначення соціальної установки запропонував сучасний американський соціолог Г. Саммерс: «соціальна установка - це стійка система поглядів та уявлень, що готує індивіда до певних дій і може бути виражена у формі відрефлексованих суджень» [11, с. 178]. В цьому контексті сучасні науковці виділяють три основні структурні компоненти соціальних установок - когнітивний, емоційно-оціночний i поведінковий (конативний), що дозволяє нам операціоналізувати поняття соціальної установки щодо корупції в українському суспільстві у вигляді трьохкомпонентної структури: 1) когнітивний компонент - когнітивні 
уявлення, судження, мисленеві конструкти в суспільній свідомості щодо розуміння корупції; 2) емоційно-оціночний компонент виражається у вигляді емоційного ставлення до корупції як соціального явища (переважно як негативне, нейтральне і позитивне); 3) конативний (поведінковий) компонент пов'язаний із готовністю індивіда виявляти певний напрямок діяльності по відношенню до проблеми корупції, тобто відображає тип поведінки щодо поширеності корупції в українському суспільстві.

Для дослідження змістових особливостей соціальних установок щодо поширеності корупції в транзитивному українському суспільстві було проведено масове соціологічне опитування серед населення України (n=2000, листопад 2019 р. - лютий 2020 р. ). Для відбору респондентів використовувалась квотна, багатоступенева вибірка що дозволило статистично відобразити населення України. В якості квот виступали вік, стать, професійна приналежність респондентів, регіон проживання.

Когнітивний компонент соціальних установок в масовій свідомості щодо розуміння сутності корупції було застосовано метод незакінчених речень. Респондентам було запропоновано закінчити речення «Корупція в українському суспільстві - це...». Всього було отримано 1876 висловлювань респондентів. За допомогою контент-аналізу висловлювань було виділено 6 категорій факторів, які обумовлюють розуміння корупції як соціального явища (рис. 1).

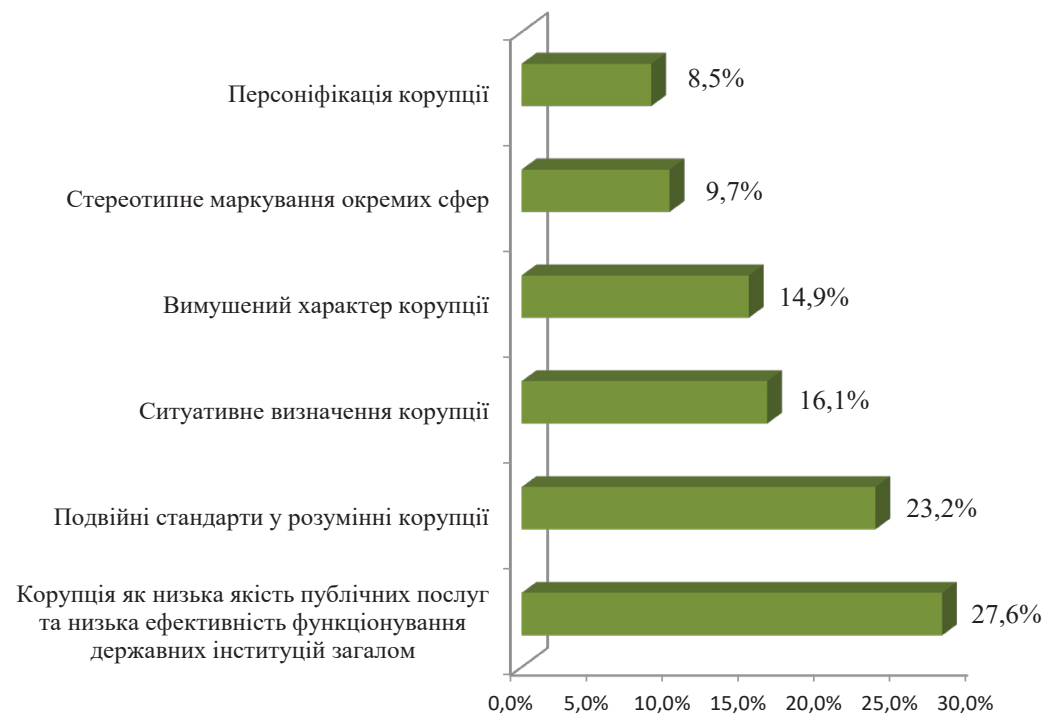

Рис. 1. Розуміння корупції як соціального явища (результати контент-аналізу) 
Формування розуміння корупції, перш за все, визначається існуванням кількох фреймів масової свідомості, які фіксують найбільш поширені в українському суспільстві стереотипи пояснення корупції та факту її існування. Розглянемо виділені семантичні категорії і наведемо типові висловлювання опитаних.

1. Корупція - це низька якість публічних послуг та низька ефективність функціонування державних інституцій загалом (27,6\% всіх висловлювань). Типові висловлювання: «вади системи», «загальне правило взаємодії з чиновниками», «недобросовісне виконання посадовцями і чиновниками своїх обов'язків», «праця чиновників завжди передбачає хабарі» тощо. Таким чином, корупція пов'язується із самою бюрократичною системою управління в Україні, де якість надання публічних адміністративних і соціальних послуг передбачає корупційні відносини із їх надавачами.

2. Подвійні стандарти у розумінні корупції (23,2\% всіх висловлювань). Аналіз висловлювань в семантичному просторі виділеної категорії дозволив виділити таку тенденцію у розумінні корупціï. 3 одного боку корупція засуджується і вважається негативним явищем, а з іншого - знаходитися маса виправдань для її існування. Дана тенденція є досить поширеною: більшість корупційних практик пояснюються традицією - так прийнято у суспільстві, так всі роблять і це не нікому шкодить, коли пояснюється особиста поведінка; і вважається злочином, коли пояснюються корупційні дії інших осіб. Типові висловлювання: «корупція вважається суспільно не прийнятною, вона засуджується засобами масової інформації», «в нашому суспільстві в більшості випадків корупція - це тільки певна вдячність чи надання необхідної допомоги», «ми звикли до того що треба «дати», щоб отримати те, що ми хочемо», «деякі корупційні дії входять в наше життя як щось звичне і не сприймаються як злочин...». Отже, в суспільній свідомості існує подвійне сприйняття і розуміння корупції як соціального явища - як засудження корупційних дій i практик, так i ii виправдовування, як «нормального явища», що спрощує соціальну взаємодію в деяких суспільних сферах (особливо в ситуаціях взаємодії із державними органами влади.

3. Ситуативне визначення корупції (16,1\% всіх висловлювань). В масовій свідомості корупція асоціюється 3 певними корупційними ситуаціями, корупційним досвідом, в які опитані найчастіше потрапляли самі або їхні родичі, знайомі. Типові висловлювання відображають такі смислові пояснювальні конструкти: 1) корупція виникає, коли чиновники створюють умови або вимагають хабаря за надання публічних послуг; 2) поділ корупції на «велику корупцію» і «побутову корупцію»; 3) корупція як спрощення процедури отримання публічних послуг

4. Вимушений характер корупції (14,9\% всіх висловлювань). Даний стереотип сприйняття корупції нагадує наведений вище виправдову- 
вальний підхід до розуміння корупції. Таким чином корупція сприймається як незаконна діяльність, однак, яка носить вимушений характер у зв'язку з тим, що у суспільстві створена така система, яка змушує осіб вдаватися до корупційних практик.

5. Стереотипне маркування окремих сфер (9,7\% всіх висловлювань). При аналізі висловлювань були виявлено чіткі тенденції щодо стереотипного маркування окремих сфер та інституцій, які асоціюються в масовій свідомості з корупцією. Серед таких інституцій виділяються заклади освіти, медичні установи, суди, правоохоронні органи, органи самоврядування різних рівнів. Слід зауважити, що на основі таких тверджень формується думка про високий рівень та розповсюдженість корупції в суспільстві в цілому.

6. Персоніфікація корупції (8,5\% всіх висловлювань). Дана тенденція виражається в асоціюванні корупції у певній сфері з певною відомою персоною, або з узагальненим образом (наприклад, «президент», «депутати», «політики», «судді», «влада», «поліція» тощо).

На емоційно-оціночному рівні більшість опитаних негативно сприймають корупції (69\% вважають їі негативним і деструктивним явищем.

Особливої уваги заслуговує виявлення типової моделі поведінки населення щодо корупційних дій і практик в суспільстві. Так, на рис. 2-3 представлено показники самоставлення опитаних до корупції і найбільш поширений тип поведінки.

Відповідно до результатів дослідження, конативний компонент соціальних установок переважно відображає пасивний тип реакції на корупційні діяння, сприйняття таких ситуацій як усталених і незмінних. Активна позиція на думку респондентів притаманна представникам окремих соціальних груп, причому опитані вважають, що більше 50\% населення готові використовувати корупцію як неформальну соціальну практику взаємодії із надавачами публічних, адміністративних і соціальних послуг.

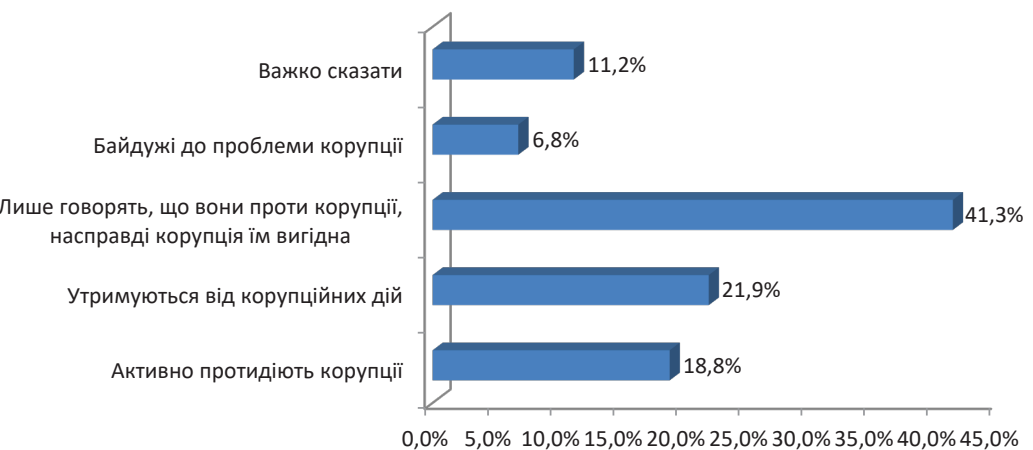

Рис. 2. Самооцінка ставлення населення до корупції 


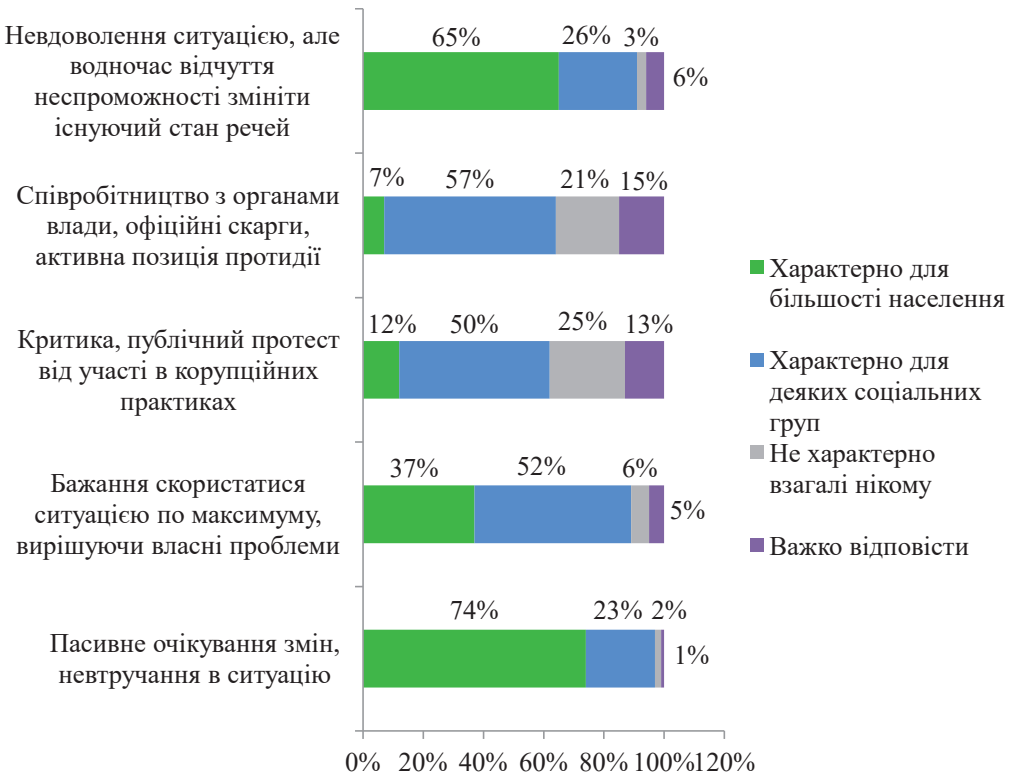

Рис. 3. Тип поведінки по відношенню до корупції в українському суспільстві

Висновки i перспективи подалыших досліджень. Результати соціологічного дослідження соціальних установок населення України щодо поширення корупції і корупційних практик в різних суспільних сферах дозволили визначити наступні змістовні особливості: 1) на рівні когнітивного компонента соціальних установок переважають такі семантичні конструкти розуміння корупції як соціального явища - корупція визначається через низьку ефективність діяльності державних інституцій (і відповідно якості публічних послуг); в масовій свідомості корупція визначається, з одного боку, як деструктивне соціальне явище, а з іншого - можливість отримати соціальну вигоду і послугу в певних соціальних ситуаціях, що $є$ подвійним стандартом у розумінні корупції; 2) на емоційно-оцінному рівні розуміння і сприйняття корупції також відображає домінування подвійних стандартів у ставленні до поширення корупційних практик в українському суспільстві; 3) змістовні особливості конотативного компоненту соціальних установок відображають тип і модель поведінки щодо корупції, причому переважає пасивність і відчуття безпорадності у протидії поширення цього явища в суспільстві - респонденти вважають, що $20 \%$ населення взагалі не виявляють таких активних форм і проявів 
поведінки як співробітництво з державними органами влади, критика, публічні виступи, протести і офіційні скарги.

Перспективним напрямком досліджень може виступити виокремлення соціальних механізмів протидії корупції і корупційних практик в українському суспільстві.

\section{Список використаної літератури}

1. Стегній О. Г. Феномен всеохоплюючої корумпованості в сучасному українському суспільстві. Украӥнський соиіум. 2012. № 1(40). С. 7-22.

2. Большой толковый социологический словарь (Collins) :у 1 т. / пер. с англ. М. : Вече. АСТ, 1999. 544 c.

3. Кузнецова Н. В. Коррупция в системе уголовных преступлений. «Круглый стол». Вестник Московского университета. 1993. № 1. С. 32.

4. Мельник М. І. Корупція - корозія влади (соціальна сутність, тенденції та наслідки, заходи протидії): монографія. Київ : Юридична думка, 2004. 400 с.

5. Бурдье П. Практический смысл / пер. с фр. А. Т. Бикбова, К. Д. Вознесенской, С. Н. Зенкина, Н. А. Шматко. СПб. : Алетейя, 2001. 562 с.

6. Хабермас Ю. Политические работы / пер. с нем. О. И. Величко. Москва : Праксис, 2005. 368 с.

7. Білінська Л. В. Корупція як соціальне, психологічне i моральне явище. Науковий вісник Міжнародного гуманітарного університету. Сер. : Юриспрудениія. 2013. №6. Т. 1. С. 138-141.

8. Креденцер О. В. , Лагодзінська В. І. , Ковальчук О. С. Теоретичний аналіз поняття «соціальна напруженість»: міждисциплінарний підхід. Актуальні проблеми психологї : зб. наук. праць Ін-ту психології імені Г. С. Костюка НАПН України. 2016. Том І. Вип. 45. С. 48-55.

9. Шихирев П. Н. Социальная установка. Социальная психология: хрестоматия: учеб. пособие для студентов вузов / сост. Е. П. Белинская, О. А. Тихомандрицкая. Москва : Аспект Пресс, 2003. С. 364-376.

10. Семечкин Н. И. Социальная психология: учеб. пособие. Владивосток : Издательство Дальневосточного университета, 2001. 152 стр.

11. Андреева Г. М. Социальная психология. Москва: Аспект-пресс, 1996. 376 с.

Chumachenko D. S. Features of social attitudes towards corruption and corrupt practices in the mass consciousness of the transitional Ukrainian society: a sociological analysis

The article examines the substantive features of social attitudes towards corruption and corrupt practices in the mass consciousness of the transitional Ukrainian society. The essence of corruption in a transitional society, which is to legitimize and institutionalize the informal regulatory system, which generates corruption at the macro level (state, social subsystems), meso-level (organizations, institutions, enterprises) and micro-level (corruption interactions of individual actors - domestic corruption). The emergence and institutionalization of corrupt practices is influenced by many factors, the weight of which can vary depending on the civilizational and social development of the country, political system, cultural and mental characteristics. It is determined that the influence of corruption-causing factors, or rather their interaction, in a transitional society creates conditions for 
institutionalization of corruption at different levels of society and social interaction, which is reflected in the emergence and dominance of certain types and forms of corrupt practices and relations. Consequently, the informal regulatory system in the form of corrupt transactions and exchanges covers various spheres of public life. The results of sociological research of social attitudes of the population of Ukraine on the spread of corruption and corrupt practices in various social spheres are presented, which allowed to determine the following substantive features: 1) at the cognitive component of social attitudes prevail perceptions of corruption, on the one hand as a destructive social phenomenon - the opportunity to receive social benefits and services in certain social situations, which is a double standard in understanding corruption; 2) at the emotional and evaluative level, the understanding and perception of corruption also reflects the dominance of double standards in relation to the spread of corrupt practices in Ukrainian society; 3) at the connotative level, social attitudes are manifested as the dominant type and model of behavior regarding corruption - passivity and helplessness in counteracting the spread of this phenomenon in society (active position is inherent in certain social groups, and more than 50\% of the population are ready to use corruption as informal social practice with providers of public, administrative and social services).

Key words: corruption, corrupt practices, factors of corruption and corrupt practices, transitional society, social attitudes. 